\title{
Identification and functional validation of a unique set of drought induced genes preferentially expressed in response to gradual water stress in peanut
}

\author{
Geetha Govind • Vokkaliga ThammeGowda Harshavardhan • \\ Jayaker Kalaiarasi Patricia · Ramachandra Dhanalakshmi · \\ Muthappa Senthil Kumar • Nese Sreenivasulu • Makarla Udayakumar
}

Published online: 18 March 2009

(C) Springer-Verlag 2009

\section{Erratum to: Mol Genet Genomics}

DOI 10.1007/s00438-009-0432-z

The Author would like to correct their names in the Author group. Instead of abbreviated form the names should change as:

Geetha Govind, Vokkaliga ThammeGowda Harshavardhan, Jayaker Kalaiarasi Patricia, Ramachandra Dhanalakshmi, Muthappa Senthil Kumar, Nese Sreenivasulu, Makarla Udayakumar.

The online version of the original article can be found under doi:10.1007/s00438-009-0432-z.

G. Govind · V. T. Harshavardhan · J. K. Patricia •

M. Senthil Kumar · M. Udayakumar

Department of Crop Physiology,

University of Agricultural Sciences, GKVK,

Bangalore 560 065, Karnataka, India

R. Dhanalakshmi

Monsanto Research Centre, Bangalore, India

V. T. Harshavardhan $\cdot$ N. Sreenivasulu

Leibniz-Institute of Plant Genetics and Crop Plant Research (IPK),

Corrensstrasse 03, 06466 Gatersleben, Germany

Present Address:

G. Govind ( $₫)$

Max Planck Institute for Chemical Ecology,

Hans-Knöll-Straße 8, 07745 Jena, Germany

e-mail: ggovind@ice.mpg.de; gee_agri@yahoo.com 